Portland State University

PDXScholar

4-28-1995

\title{
Insoluble Ambiguity: Criticism and the Structure of the Frame Narrative in The Turn of the Screw by Henry James
}

Cecilia Rosenow

Portland State University

Follow this and additional works at: https://pdxscholar.library.pdx.edu/open_access_etds

Part of the English Language and Literature Commons Let us know how access to this document benefits you.

Recommended Citation

Rosenow, Cecilia, "Insoluble Ambiguity: Criticism and the Structure of the Frame Narrative in The Turn of the Screw by Henry James" (1995). Dissertations and Theses. Paper 4908.

https://doi.org/10.15760/etd.6784

This Thesis is brought to you for free and open access. It has been accepted for inclusion in Dissertations and Theses by an authorized administrator of PDXScholar. Please contact us if we can make this document more accessible: pdxscholar@pdx.edu. 
The abstract and thesis of Cecilia Rosenow for the Master of Arts in English were presented April 28, 1995, and accepted by the thesis committee and the department.

COMMITTEE APPROVALS:
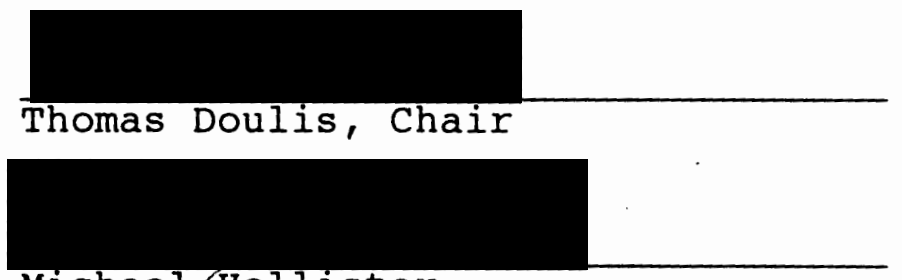

\section{Michael Hollister}
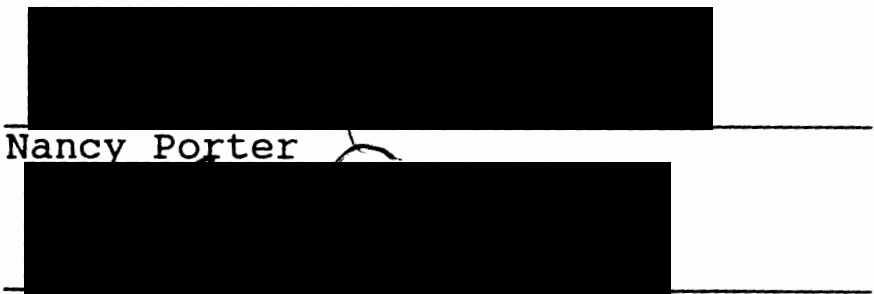

RIChard Toscan

Representative of the office of Graduate studies

DEPARTMENT APPROVAL:

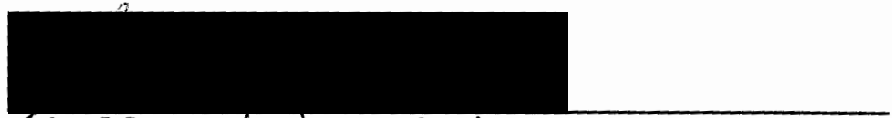

Shelley Beece, Chair Department of English

ACCEPTED FOR PORTLAND STATE UNIVERSITY BY THE LIBRARY

by on

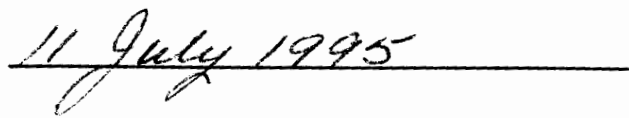




\section{ABSTRACT}

An abstract of the thesis of Cecilia Rosenow for the Master of Arts in English presented April 28, 1995.

Title: Insoluble Ambiguity: Criticism and the structure of the Frame Narrative in The Turn of the Screw by Henry James .

Since its publication in 1898, The Turn of the Screw has been the focus of diverse critical interpretation. It has reflected shifts in critical theory that include the Freudian, psychoanalytic, mythological, structuralist, reader-response, linguistic, and new-historical schools.

The majority of critical interpretations have focused on the governess's narrative and have excluded the prologue, or frame narrative, that begins the novella. The critics who did examine the prologue overlooked James's departure from the traditional use of frame narration and the importance of the structure of the frame in creating a text of insoluble ambiguity.

James departed from traditional frame narration in four ways. By using only an opening frame, the reader is forced to rely on the prologue in order to determine narrative reliability. By creating a condition of reciprocal authority between the unnamed narrator and Douglas, the opening frame denies the possibility of using either character to substantiate the reliability of the other. 
The condition of reciprocal authority is constructed through a dialogue pattern in which the narrator and Douglas interpret each other's gestures and comments and finish each other's sentences. It is the use of the pattern in the prologue that prepares the reader to accept it in the governess's narrative. The governess repeats the dialogue pattern with Mrs. Grose and Miles. Their discussions appear to validate the governess as a reliable narrator when in fact her reliability is as impossible to determine as the reliability of Douglas or the frame narrator. The result of these departures from traditional frame narration is the construction of a text of insoluble ambiguity. 
INSOLUBLE AMBIGUITY:

CRITICISM AND THE STRUCTURE OF THE FRAME NARRATIVE IN THE TURN OF THE SCREW BY HENRY JAMES

by

CECILIA ROSENOW

A thesis submitted in partial fulfillment of the requirements for the degree of

MASTER OF ARTS

in

ENGLISH

Portland State University

1995 
TABLE OF CONTENTS

PAGE

ACKNOWLEDGMENTS . . . . . . . . . . . . . . . . iii

CHAPTER

I INTRODUCTION . . . . . . . . . . . 1

II A SURVEY OF CRITICISM ON THE TURN OF THE SCREW 4

III THE HISTORY OF THE FRAME NARRATIVE . . . . . 25

IV A STRUCTURAL EXAMINATION OF FRAME NARRATION IN THE TURN OF THE SCREW . . . . . . . . . . . 35

$\mathrm{V}$ CONCLUSION ............. 63

WORKS CONSULTED AND CITED .............. . 66 


\section{ACKNOWLEDGMENTS}

I am especially grateful to the following people for their assistance and support in the completion of this thesis: Thomas Doulis, for his courses on Henry James, his assistance with the structure and content of each section of the thesis, and his willingness to act as advisor on this project; Michael Hollister, for his editorial comments at each stage in the development of this text and for serving as the official thesis reader on the examining committee; Nancy Porter, for suggestions in the direction of the thesis that allowed for the greatest amount of original work on such a well-studied text; and Sarah Koch, for timeless hours of copy-editing and proofreading, and for her constant support and interest in the study of Henry James. 
CHAPTER I

\section{INTRODUCTION}

Since its publication in 1898, The Turn of the Screw has been the focus of intense critical debate. This debate encompasses shifts in critical thinking which include Freudian, psychoanalytic, mythological, structuralist, readerresponse, linguistic, and new-historical critical theories. Although these shifts bring with them an ever-changing interpretation of the text, the majority of critical approaches have consistently overlooked the importance of the prologue. In his construction of the prologue, James departed from the traditional use of the frame narrative, using it to create a novella of insoluble ambiguity by denying closure and preventing the determination of narrative authority.

The prologue begins on Christmas Eve with a group of guests gathered around a fireplace exchanging ghost stories. An unnamed, first-person narrator has described the group's interest in a ghostly visitation experienced by a child, as told by one of the guests. The narrator then introduces Douglas, who announces that he has a ghost story involving two children. Douglas's sister's governess had experienced the ghostly encounter first-hand while in charge of the two children, and he possesses her hand-written account of the 
tale.

Two days later, Douglas receives the manuscript in the mail, but before he begins to read he provides the guests with background information on the woman who, at the time of her death, had given him the manuscript. The woman, who remains unnamed, was the daughter of a country parson. She had been hired for her first employment by a bachelor who was the uncle and legal guardian of two children, Miles and Flora. Her employer had made clear that, as their governess, she was to be completely in charge and was never to contact him again.

Douglas then begins to read from the governess's manuscript and the remainder of the novella is told from the governess's first person point of view. The governess describes her belief that Miles and Flora are in danger of being possessed by two ghosts. She believes that she personally encounters these ghosts and that the children also see them but will not admit it. As no one else at BIy acknowledges their presence, the governess believes it is her responsibility to save the children's souls.

The governess recounts her discussions with the housekeeper, Mrs. Grose, about the children's strange behavior. It is through these discussions that the governess comes to believe that the ghosts are her employer's former servant, Peter Quint, and her own predecessor, Miss Jessel. The governess determines that she must force the children to admit their interaction with these ghosts if she is to save 
them. The novella ends when Miles finally states the name, Peter Quint, and dies in the governess's arms.

The majority of critical approaches applied to the novella have focused on the governess's narrative and have been divided between the apparitionist and the nonapparitionist readings. The apparitionist reading believes that the ghosts exist, whereas the non-apparitionist reading believes that the ghosts are hallucinations of the governess. Some critics, in attempting to synthesize these different interpretations, have recognized the novella's insoluble ambiguity as inherent in the text's structure but have continued to focus their examinations on the governess's narrative. While a few critics have examined the prologue, they have overlooked much of its importance in departing from traditional frame narration and in the construction of the text's insoluble ambiguity. 


\section{CHAPTER II}

\section{A SURVEY OF CRITICISM ON THE TURN OF THE SCREW}

The critical history of The Turn of the Screw begins with book reviews of The Two Magics, in which the novella appeared with another work, Covering End. Most of these reviews are favorable. The unfavorable reviews, as Edward Parkinson notes in his dissertation, "The Turn of the Screw": A History of its Critical Interpretations, 1898-1979, are primarily due to a "Victorian puritanism upon perceiving suggested sexual material in the plot of the novella" (44).

While the reviews focus on the text as a ghost story, they also casually suggest elements of the text which will later make up the majority of critical approaches to the novella, particularly those of the apparitionist/nonapparitionist debate. For instance, The Critic mentions that the governess might not be a reliable narrator. Literature and the New York Times Saturday Review of Books and Art note that the novella contains intentional ambiguity. Although early reviews provide the first instance of some of these insights, it is not until the Freudian non-apparitionist interpretation of the text that the critical debate truly begins.

The Freudian critics believe that there are no apparitions. The governess is a sexually repressed young woman 
who is attracted to the bachelor uncle. As the daughter of a country parson, she is unable to accept this attraction and projects her feelings onto two figments of her imagination. The ghost of Peter Quint represents the object of her desire. Miss Jessel represents the repressed part of the governess, the part of her that desires the uncle and which her conscious mind cannot acknowledge. Other elements of the Freudian reading include the suggestions that the governess is sexually attracted to Miles and that there had been a homosexual relationship between Peter Quint and Miles.

The first critic to publish an article suggesting that the apparitions are not real is Edna Kenton, in "Henry James to the Ruminant Reader: The Turn of the Screw" (1924). It contains the lines that were cited for many years as the first Freudian interpretation of James's novella. Kenton states that the reader,
persistently baffled, but persistently wondering, comes face to face at last with the little governess, and realizes, with a conscious thrill greater than that of merely automatic nerve shudders before 'horror,' that the guarding ghosts and children - what they are and what they do - are only exquisite dramatizations of her little personal mystery, figures for the ebb and flow of troubled thought within her mind (113).

Although Kenton notes that the ghosts are hallucinations brought about by the governess's mental state, it was not until Edmund Wilson's article, "The Ambiguity of Henry James," Hound and Horn (April-June, 1934), that the Freudian 
interpretation received serious recognition. Where kenton only describes the "troubled thought within her [the governess's] mind," Wilson applies Freudian psychology and specific terminology to the entire text:

The theory is, then, that the governess who is made to tell the story is a neurotic case of sex repression, and that the ghosts are not real ghosts but hallucinations of the governess (115).

In 1957, an essay appeared which was ultimately determined to be the first non-apparitionist interpretation of The Turn of the Screw. "A Pre-Freudian Reading of The Turn of the Screw" was written by Harold C. Goddard in or before 1920 . Goddard's daughter, Eleanor Goddard Worthen, stated that her father was a professor in English and had read the essay to his classes but had never published it. Leon Edel verified that the essay must have been written before 1921 because it mentions no one other than William Lyon Phelps.

In 1916, Phelps published an article in The Yale Review in which he described his interchange with Henry James regarding the terror produced by The Turn of the Screw. Phelps believed the story to be "the most powerful, the most nerveshattering ghost story" (Phelps 178) he had ever read. James responded by telling Phelps he was pleased that the story had achieved the desired effect and described the lack of reaction by the stenographer when James had dictated the tale, stating, "'this iron Scot betrayed not the slightest shade of feeling'" (178). 
While many other critics have applied a Freudian reading to the novella, Edmund wilson has remained the acknowledged leader of the Freudian side of the debate. Other writers applying a Freudian approach to the novella during the same time period include Stephen Spender, 1935, Ivor Winters, 1937, and Robert Liddell, 1947.

Those who oppose the non-apparitionist theory aim their denunciation of the Freudian interpretation at wilson. In 1947, Robert Heilman's essay, "The Freudian Reading of The Turn of the Screw," and A.J.A. Waldock's essay, "Mr. Edmund Wilson and The Turn of the Screw," take exception to Wilson's argument. Heilman cites James's comments from the Preface to Volume 12 of the New York Edition to argue that James intends the governess to be a credible character. Waldock suggests that Mrs. Grose's identification of Peter Quint refutes the Freudian reading of the tale.

Elmer Edgar Stoll, in 1948, states that the critics are simply reading too much into the text and cites Douglas's description of the governess's character to defend an apparitionist reading. Robert Liddell, in $A$ Treatise on the American Novel, also uses Douglas's support of the governess to rebut the Freudian interpretation.

Some of the apparitionist critics attack the nonapparitionists with quotes from the text. Others, such as Nathan Bryllion Fagin, suggest that James could not have known of Freudian psychology and therefore was not likely to have 
used it in his story. The belief that James could not have known of this psychology is countered, however, by examining James's interest in mental disorders, the occult, and psychology as well as by examining the more in-depth work that William James conducts in these areas. Fagin also suggests that the tale could be a moral allegory, such as those written by Nathanial Hawthorne, thereby mentioning what will become one of the most significant apparitionist approaches when it is later elaborated upon by Robert Heilman.

As a growing number of critics agree with the apparitionist criticism, the strict Freudian reading shifts in focus from Freudian sexual repression to a more in-depth psychoanalytical approach which focuses on James as well as on the novella. Edmund Wilson and Leon Edel each examine the author as well as the text, pointing to the failure of James's play, Guy Domville, as a contributing influence on the Turn of the screw. This failure affects James's own psychological state when he first hears from Archbishop Benson the story which he will develop into The Turn of the Screw. Wilson, in 1948, sums up his interpretation of the story by stating, "One is led to conclude that, in The Turn of the Screw, not merely is the governess self-deceived, but that James is selfdeceived about her" (Wilson 147).

In 1948, while many critics continued to follow the psychoanalytical approach, Robert Heilman published what became the benchmark essay for the apparitionist argument. 
"'The Turn of the Screw' as Poem" explores the many Christian mythological references in James's text and states, "we have the oldest of themes - the struggle of evil to possess the human soul" (175).

Heilman's examination of the text goes beyond the basic argument as to the existence of the ghosts. He explains that, at the level of action, the apparitions are real; however, there is also symbolic import to the dramatic circumstances (175). It is this symbolic import which is the focus of Heilman's essay. The ghosts represent an evil which comes subtly and conquers before it is completely seen. The governess recognizes this evil on an intuitive level. It is her duty, then, to detect and try to ward off the evil when it appears. In this reading, the governess stands in direct opposition to Mrs. Grose, whose allegorical significance is as a commonplace mortal. She has good intentions but is able to perceive only obvious evil as opposed to the subtle evil perceived by the governess.

To support his claim that the tale is a moral allegory told as a ghost story, Heilman examines the role of language and its effect on the tone and meaning of the story. Names, for instance, hold particular significance. Miles signifies the soldier, the archetypal male, while flora represents the flower, the essential female (179).

The children are always described using universal descriptions of light, such as "radiance," "dazzle," and 
"glitter." According to Heilman, their beauty is symbolic of the spiritual perfection humanity has the potential to achieve (178). The references to light in addition to those of innocence lead Heilman to suggest that the descriptions of the children are " . . echoes of the Garden of Eden . . " where ". . Miles and Flora become the childhood of the race" $(178) \cdot$

Heilman also traces references to the Miltonic myth, particularly with respect to the apparitions. Miss Jessel, he states, is the image of someone who is damned but is also an agent of damnation (182). Peter Quint is described with the attributes of a snake, again recalling the Garden of Eden.

Heilman concludes that the governess, herself, has spiritual qualities. He states that, ". . James is attaching to her the quality of savior, not only in a general sense, but with certain Christian associations" (184). It is the governess's role as savior that alters her relationship with Miles from one of a sexual nature, as interpreted by the Freudian critics, to one of pastoral love. Heilman views the final scene of the story as a confessional with the governess acting as a priest attempting to save Miles from evil (185).

Christian mythology is not the only mythological approach taken to The Turn of the Screw. Mary Y. Hallab, in her essay, "The Governess and the Demon Lover: The Return of a Fairy Tale," explores the Jungian archetypes in the story. She points to similarities between the governess and the young 
women of two fairy tales, "Cherry of zennor" and "The Fairy Widower." Both fairy tales were published in Robert Hunt's Popular Romances of the West of England in 1865. Hallab suggests that the similarities are not coincidental and that it is probable that James knew about the fairy tales.

There are plot similarities between The Turn of the Screw and the two fairy tales. In each of the stories, a young woman from a poor family is hired by a handsome gentleman for the purpose of child care (106). At first, the woman is delighted with her new employment but eventually this gives way to ambiguous and upsetting realities involving the children under her care (107). Other similarities include a change in the employer from a handsome man to a demonic figure, a distant journey undertaken by the young woman to reach her place of employment, and the description of her place of employment as a large house filled with mysterious rooms (106).

Hallab also suggests that The Turn of the Screw and the two fairy tales represent an archetypal journey. The story

can be seen as a journey into the fairyland or demon world within the human psyche, where the ego-centered, everyday self confronts the darker aspects of sexuality, evil, death, represented by means of the archetypal pattern of the human maiden led into the other World by a 'demon lover' (109).

She notes that the text contains many archetypes that support her reading. The uncle represents the "patriarchal archetype" who believes that all women are to be possessed and used (110). The demon lover, or Peter Quint, is the Animus, 
"standing for the collective unconscious as projected by the female psyche, for all that is fearful to her of evil, death, the unknown and uncontrollable" (110). To survive her encounter with the Animus, the governess needs to gain knowledge of her unconscious without succumbing to its demonic possession because this would result in "the subsequent annihilation of Self" (110).

The children represent the archetype for wholeness of being, the wholeness pursued by the governess when she faces her collective unconscious. Hallab cites Jung's definition of the Child archetype as "the primitive and undifferentiated conscious and unconscious, which yet represents the potential for . . the integrated self" (111).

Through her exploration of the archetypal components of The Turn of the Screw, and her comparison of the text to the two fairy tales, Hallab suggests that the fairy tales are, if not the actual source of James's story, strong influences upon the novella. Other critics search not for influences, but for the actual source of James's story. In his January 12, 1895 notebook entry, James cites his discussion with Archbishop Benson and the anecdote upon which James's story is based. Benson's sons, however, later note that they do not remember ever hearing this story from their father nor of his sharing any such anecdote with Henry James. Even so, many critics believe that part of the story may have come from the Archbishop. 
While some critics are satisfied that the source of the story is the Archbishop's anecdote, others disagree and continue to search for the tale's origins. Francis $x$. Roellinger, in 1949, suggested that the proceedings of the Society for Psychical Research contributed to James's story and to an apparitionist reading of the text. Not only is James known to have attended occasional meetings of the Society, his brother William is recognized as having been an active member. Roellinger points to references in James's notebooks regarding the Society and its work.

Oscar Cargill, however, follows a non-apparitionist approach to the source of the novella in his essay, "Henry James as Freudian Pioneer." To support his Freudian interpretation, Cargill suggests possible sources for the tale, one of which is the illness of Alice James. Cargill states that, through Alice, James's "personal knowledge of hysteria - . makes it clear that Miss Kenton and Edmund Wilson were profoundly right" (164). He also suggests that James's decision to leave the governess unnamed is an unconscious effort to hide the fact that she is based on his own sister.

Other efforts to locate the source of James's story include that of Leon Edel and Adeline Tintner. In their 1985 article, "The Private Life of Peter Quin[t]: Origins of 'The Turn of the Screw," they cite "Temptation," a story by Tom Taylor, as the basis for James's tale. They suggest that 
James, who admittedly read magazines such as Punch, is likely to have read Taylor's story when it was serialized from January to June 1855 in Frank Leslie's New York Journal of Romance, General Literature, Science and Art.

"Temptation" includes characters named Peter Quin and Miles as well as an old man named Griffiths whose name could have been altered to Griffin, the character in the frame story. There is also a country house, Brierly Grange, whose name could have been contracted to Bly (3). Plot similarities, publication in a magazine similar to Frank Leslie's, and publication during the same season in which Taylor's story had originally appeared, led Edel and Tintner to conclude, "It was as if he were rewriting the old thriller" (3).

While some critics avoid the apparitionist/nonapparitionist debate by searching for the influences on James or for the source of the story, others attempt to synthesize the two polarities. These critics suggest that the correct reading is not apparitionist or non-apparitionist, but both. The first critic to attempt this synthesis is John Lydenberg. According to Edward Parkinson, Lydenberg considers the elements of the story noted by Heilman, but he places them in the context of the work as a whole. He considers the narrative structure of the governess's tale and the information, albeit not the narrative structure, of the prologue. Using Douglas's description of the governess, Lydenberg then applies psychoanalytic theory. He explores the governess's tendency to 
find evil in others due to her own pride. He finds her psychology to be of a "particular religious type and sees in the story a criticism of that New England Puritanism with which James was so familiar" (192). Parkinson notes that, by doing so, Lydenberg is

able to integrate Heilman's masterful
insights into the story's religious
motifs with wilson's insights concerning
the shortcomings of the governess and the
origins of these shortcomings in her
individual psychology as it reacted to
the situation in which she found herself
at Bly (188-89).

Until the 1960s, the critical debate confined itself to the apparitionist, non-apparitionist, and synthesized interpretations of the novella. A group of structuralist critics developed, however, and suggested that any reading which sought to provide a final interpretation of the novella was inaccurate because the text's ambiguity was insoluble.

Critics such as Walter F. Wright, Muriel G. Shine, J.A. Ward, and Dorothea Krook believe that the ambiguity is deliberate on the part of James and that it is inherent in the novella's structure. It is the insoluble ambiguity which allows for so many different readings of the text, most of which find their support in the text itself. However, although the structuralist critics agree that the ambiguity is deliberate, they are not in agreement as to its purpose.

Wright suggests that the ambiguity is intended to impart insights to the reader regarding the human condition, "most importantly that we can never know the whole truth and yet 
must act in contexts where mistaken action can bury us in guilt" (Parkinson 297). In his reading of the text, the governess is a sympathetic character representing a critical truth about the human condition.

Shine also agrees that the story centers on the "etirical problems of acting in the light of incomplete knowledge" (299); however, unlike wright, she believes that the governess represents the incorrect means of attaining knowledge. Shine suggests that one must first possess self-knowledge before attempting to attain knowledge outside of oneself.

Ward also believes that the ambiguity is intentional but examines the ambiguity in light of James's body of work during the middle segment of his writing career. He aligns the "Puritan concern with evil and a transcendentalist concern with experience" (304) in The Turn of the Screw with other works by James such as "The Beast in the Jungle." He suggests that the governess is consistent with other characters representing human imperfection.

Krook, like ward, examines the text with respect to other works by James during the same time period. She takes a philosophical approach, suggesting that the ambiguity in the text is not only insoluble but that it allows the governess to dramatize "the co-existence or co-presence of good and evil in the human soul" (315).

The first structuralist critics propose the insoluble ambiguity of the text through an examination of the use of the 
first person, limited omniscient narrator of the governess as well as through comparisons with James's other works. Their focus, however, is limited primarily to the governess's narrative. If the prologue is examined at all, it is to invoke Douglas's comments about the governess but not to examine the structure of the frame.

In the late 1970s, three critics examined the structure of the text and its relationship to the reader's response. They examined the opening frame as an important key not only to understanding the insoluble ambiguity but to exploring the effect of the ambiguity upon the reader. However, they still overlooked James's departure from the traditional frame narrative and the insights they did have were often obscured by their focuses on larger critical theories.

The first of these critics is Shoshana Felman. Felman's article focuses primarily on the relationship between literature and psychoanalysis. She examines the definition of a Freudian reading and explores the critical debate surrounding the apparitionist and non-apparitionist views. She also explores the governess's narrative, the importance of writing and reading within the novella, and the role of the bachelor uncle.

Only one section of the article focuses exclusively on the prologue. In this section, she notes that the prologue occurs after the events at Bly have transpired yet contains information and events which occurred before the events of the 
governess's tale. The result is a temporal framing of the governess's narrative.

Felman also suggests that the tale's ambiguity is centered in the narration of the opening frame. She notes that

the story's origin seems to depend on the authority of the story teller, i.e., of the narrator, who is usually supposed to be both the story's literal source and the depository of the knowledge out of which the story springs and which the telling must reveal. But while the prologue's function would thus seem to be to relate the story to its narrator, the prologue of The Turn of the Screw rather disconnects the story from the narrator since it introduces not one narrator, but three . . . The story's origin is therefore not assigned to any one voice which would assume responsibility for the tale, but to the deferred action of a sort of echoing effect, produced -'after the fact' -- by voices which themselves re-produce previous voices [italics Felman](Felman 530).

Felman also examines the parallel relationship between the unnamed narrator and Douglas with that of Douglas and the governess. She notes that mutual admiration among the narrators causes all three narrators to be suspect in terms of their reliability.

Felman suggests that the effect of the frame's narration disallows for an innocent reader. Either a reader believes the governess and acts like Mrs. Grose by not questioning her story, or the reader does not believe the governess and becomes as suspicious as the governess herself.

Peter A. Obuchowski comments on the triple narration of the novella, as well, agreeing with Felman that "James uses 
the frame to confuse further the center of authority" (Obuchowski 537). Obuchowski questions Douglas's reliability in describing the governess when the relationship between Douglas and the governess is still unknown to the reader. He also questions the unnamed narrator's support of Douglas and the reliability of the governess's manuscript in the hands of either of these frame narrators. His examination of the frame stops at this point, and his focus shifts to the effect of the confusion of authority upon the reader. He ultimately agrees with Felman in her suggestion that the reader must operate in ways similar to those of the governess or Mrs. Grose.

Kevin Murphy, also, examines the structure of the frame narrative. He notes that the "apparent agreement between Douglas and the first narrator . . mirrors the apparent agreement between the governess and Mrs. Grose" (Murphy 540). He believes that the parallel collaboration between these characters only further confuses the reader. The reader's first impression is that Douglas and the governess are reliable. Only later does it become apparent that this assumption is based on the testimony of an unreliable supporter, the frame narrator.

In 1982, Michael J. H. Taylor examined the structure of the frame narrative in his article, "A Note on the First Narrator of The Turn of the Screw." He provides relatively little new information, however, after the work of Felman, Obuchowski, and Murphy. Taylor focuses on the "special, almost 
telepathic, understanding between Douglas and the narrator" (719), noting how the dialogue between Douglas and the narrator demonstrates their mutual esteem. Taylor also suggests that the frame narrative is so ambiguous that the unnamed narrator could be a woman as well as a man and reminds the reader that James, himself, warns against making any assumptions.

Studies of the intentional ambiguity of the text ultimately led not only to an examination of the text's narrative structure but also to the use of linguistics. In the late 1970s, this approach was taken by Christine Brooke-Rose in her articles, "Surface Structures in Narrative," "The Squirm of the True - An Essay in Non-Methodology," and "The Long Glasses - A Structural Analysis," as well as in her book A Rhetoric of the Unreal. It was also used by Shlomith Rimmon, in The Concept of Ambiguity - the Example of James.

A linguistic approach to the text is also taken by Darrel Mansell in his 1985 article, "The Ghost of Language in the Turn of the Screw." Mansell examines the many ways in which words have meanings and applies this to the lack of an epilogue in James's text:

The prologue brings into being the governess' narrative; the narrative in turn brings into being - nothing possible beyond itself, no epilogue. This story perversely turns away from verisimilitude - . and turns itself into a text with no reference beyond its literal self. Words themselves, not the dimensions of reality they can be made to refer to, are the story's power. Words, even words that 
are saying what is not and that are extended nowhere, can scare up ghosts to haunt the printed page itself [italics Mansell] (63).

Bruce E. Fleming, in his 1989 article "Floundering About in Silence: What the Governess Couldn't Say," focuses on the effect of silence and unfinished statements upon the text and relates it to a greater understanding of James's work in general.

In 1991, two articles appeared which examined the language of James's text. Jose Antonio Alvarez Amoros published "Possible-World Semantics, Frame Text, Insert Text, and Unreliable Narration: The Case of The Turn of the Screw," and Helen Aristar Dry and Susan Kucinkas co-authored "Ghostly Ambiguity: Presuppositional Constructions in The Turn of the Screw."

Amoros forms a new theory for unreliable narration and examines the role of frame text and insert text within this theory. He defines frame text as the information verbalized by a narrator and insert text as the information quoted by a narrator. He notes that these two types of text "so clearly distinguished in theory, become frequently confused in the microstructural level of a specific narrative" (49) and explores the importance of indicators to signal a shift from frame text to insert text. While Amoros examines the governess's narrative, he does so only as a brief illustration of the primary focus of the article, which is his linguistic theory of unreliable narration. 
The Dry/Kucinkas article examines the different ways in which information is presented to the hearer and therefore to the reader, particularly in terms of the use of presuppositional constructions in the text. The authors define presuppositional constructions as "syntactic structures that, in normal conversation, evoke a type of pragmatic inference difficult either to verify or to challenge" (71). They cite as an example the governess's tendency to present new information about the ghosts "as though it were already assumed by both the speaker and the hearer" (71). Dry and Kucinkas conclude that James's syntax contributes significantly to the tale's ambiguity because, on close examination, it calls into question the governess's reliability as a narrator.

While many of the critical interpretations of The Turn of the Screw in the 1980s and '90s focus on the language, semantics, and syntax of the text, some critics remain dissatisfied with earlier work on the narrative style and the source of James's text. For instance, William R. Goetz examines the different types of narration in the text in his 1981 article, "The 'Frame' of The Turn of the Screw: Framing the Reader In." He suggests that the frame narrative is James's means of instructing the reader as to how to read the story.

Goetz also notes that the frame and the governess's narrative demonstrate different types of narration, each with its own type of meaning and authority. For instance, the frame 
narrative is an oral storytelling scene which introduces a written narrative (71). Within the governess's written narrative, however, are oral scenes. Ultimately, he suggests that the narrative structure of the novella "obliges the reader to choose one reading and at the same time to see the inadequacy of his choice. The governess's choice has been to believe in the ghosts. Her dilemma, which is also ours, is that of being given an authority of which she is not really capable" (74).

In 1989, Peter G. Beidler stepped away from the critical focus on the text and attempted to locate the story's source. Through a new historical approach, his book Ghosts, Demons, and Henry James: The Turn of the screw at the Turn of the Century explores James's novella as a serious ghost story. Beidler states, "The time has come in the history of the criticism of The Turn of the Screw. - . to try to reorient ourselves, away from the assumptions prevalent at the end of the twentieth century and toward the assumptions prevalent at the end of the nineteenth" (13).

Beidler examines 2,000 cases involving ghosts. He explores actual accounts of ghost stories James is likely to have heard when he was young, fictional ghost stories written by James's contemporaries, and the impact upon James of the Society of Psychical Research. In suggesting that James only intended to write a ghost story similar to other ghost stories of the nineteenth century, Beidler places all of the story's 
importance on its subject matter. He misses the importance of James's crafting of a text which is considerably different from other nineteenth-century ghost stories. However, Beidler's work is consistent with the entire critical history of The Turn of the Screw. Critics have routinely pulled out a single element of the story, be it structure or subject or the author's psychology, by which to provide the final interpretation of the entire novella.

Only three critics, Felman, Obuchowski, and Murphy, by examining the structure of both the frame narrative and the governess's tale, as well as by exploring how the text's ambiguity affects the reader, come close to providing a complete analysis of James's story. Even so, these critics do not fully examine the frame narrative, particularly in terms of how James departs from the traditional use of this convention. Instead, they select one or two characteristics for their focus, leaving the frame narrative the most unexplored yet most important step toward completing an examination of The Turn of the Screw. 
THE HISTORY OF THE FRAME NARRATIVE

The frame narrative, or framework-story, has been an established literary convention since the fifteenth century. Early examples of frame narratives, such as The Thousand and One Nights, Decameron, and The Canterbury Tales, present a series of stories within a larger framework.

The Thousand and One Nights, or Arabian Nights Entertainments, is thought to have been constructed during the fifteenth century. It first appears in Europe in the seventeenth century and becomes popular reading for children in the nineteenth century with the advent of the first complete English translation.

The frame narrative introduces king Shahriyar, a ruler whose first wife had been unfaithful to him and who subsequently kills each of his new wives on the morning after their wedding. When he marries Scheherazade, however, she saves her own life by entertaining the king with a series of stories. Scheherazade's stories make up the framed narrative.

Boccaccio, in his fourteenth-century collection of tales, Decameron, uses a frame narrative to present one hundred stories. The framework tale consists of a group of three men and seven women who have left Florence to escape the plague. 
Each character tells one story a day for ten days. The framed narrative consists of these tales. The frame, in this instance, is used to launch the series of stories, and the narrator of each tale is not particularly important insofar as "the reassignment of all the stories to different speakers would not materially change the effect" (Abrams 85). Boccaccio does not develop a plot in the framework, only separate plots within the individual stories.

Geoffrey Chaucer uses a more advanced version of the framework story in his fourteenth-century work, The Canterbury Tales. The framework consists of a group of travellers making a pilgrimage and contains its own plot. Through the General Prologue, the narrator imparts information regarding each of the pilgrims. Twenty-two tales follow the General Prologue, each told by one of the travellers. Chaucer creates a relationship between the pilgrims and the stories they tell. The characters are developed not only by the information in the General prologue but by their own stories and by the reaction of the other pilgrims to different tales. Each individual story "takes on rich overtones from what we have learned of its teller in the General Prologue and elsewhere" $(85) \cdot$

The frame narrative is also used in novels to present a single story within a story, examples of which can be found in the nineteenth century when James wrote The Turn of the Screw. For instance, Frankenstein by Mary shelley and wuthering 
Heights by Emily Bronte both use the technique of frame narration.

In Frankenstein, a framework is constructed through the letters of $R$. Walton to his sister. Walton, on a journey to the North Pole, encounters Victor Frankenstein, and he writes of his new friend in his letters. He realizes that Frankenstein has a secret to impart and that he will likely see his sister in person before he can send the letters to her, so Walton decides to keep a journal of Frankenstein's story. He plans to present it to his sister when they meet so that she may read an accurate account of the events and so that he will be able to re-read the story in the future.

The framed narrative consists of Frankenstein's tale, which he presents in the first person. Shelley takes the tale's narration a step further, however, by having Frankenstein stop his narrative, sit down, and listen to the monster's own story told by the monster in the first person. Frankenstein then picks up his narrative again and finishes it, at which time Walton concludes the narration of the novel. The closing frame is narrated by Walton, who describes Frankenstein leaping from the ship's cabin window onto an ice raft and floating away on the sea.

Wuthering Heights exemplifies a further development in novels using the frame narrative. The framework tale is told in the first person by Mr. Lockwood, a tenant of Thrushcross Grange, who visits his landlord, Heathcliff, at wuthering 
Heights. Mr. Lockwood's visits to Wuthering Heights and his encounters with the inhabitants construct the fully developed tale which begins and ends the novel. Framed within Mr. Lockwood's tale is the story of Catherine and Heathcliff, which is told by Mr. Lockwood's housekeeper, Mrs. Dean. Bronte presents the framed tale in pieces, switching the point of view between Mr. Lockwood, Mrs. Dean, and Mr. Lockwood presenting Mrs. Dean's point of view. Yet, with all of the changes in narrative perspective, Bronte never violates point of view but instead uses the changes to maintain the novel's suspenseful tone.

At Mr. Lockwood's urging, Mrs. Dean tells the framed story which begins during her early days at Wuthering Heights. She does not, however, present her story in a single telling. She breaks off her narrative because it is late at night and does not resume for a period of three weeks, a period narrated by Mr. Lockwood. She begins the next part of her story but breaks off for a second time. Mr. Lockwood states that he ultimately learns the tale at intervals but he will present it to the reader in a single telling and from Mrs. Dean's point of view.

The closing frame provides the remainder of $\mathrm{Mr}$. Lockwood's own narrative after that of Catherine and Heathcliff has been concluded. It also includes another, shorter framed narrative which is an extension of the first framed narrative told by Mrs. Dean. Mr. Lockwood narrates from 
his own first-person point of view covering both his departure and his return to Thrushcross Grange. Upon his return, he requests that Mrs. Dean inform him of the changes which have occurred during the past one and a half years. After Mrs. Dean has finished her extension of the framed narrative, Mr. Lockwood takes up the narration and concludes the framework story. The result of switching the point of view many times and of inserting an extension of the framed narrative into the closing frame is two-fold. It integrates the two tales so that each may help develop the plot and characters of the other. It also assures a consistency of tone between the framework and the framed narrative.

Short fiction, a new genre in the nineteenth century, also used the technique of frame narration. Periodical publishers, by restricting the number of words a story can contain, forced writers to begin narration of their primary tale quickly. The frame narrative provided a means of introducing the main, framed story, establishing a reason for telling the framed tale, and providing credibility for its narrator. The artistic use of this convention varied among short fiction writers, as seen in the following examples by three of James's contemporaries: Maupassant, Twain, and Chekhov.

Guy de Maupassant presents the tale of "The Model" using a frame narrative. The frame is told by a third-person narrator. It consists of two young men watching a man walking 
by the side of a woman who is being pushed in a wheelchair by a servant. One of the young men states that he knows the history of the couple's marriage and how the woman obtained her injured legs and was forced to spend her life in a wheelchair. He then narrates the framed tale, and in doing so discloses his own involvement in the story, casting suspicion on his entire narrative.

According to the young man, the husband was a famous painter and the wife had been his model. They had an affair but when the painter tried to end it, the model became very upset. She demanded that the painter continue their relationship. The narrator admitted that he was a friend of the painter and that he tried to talk the woman out of her demand. It was the narrator who told the woman that the painter had plans to marry someone else. After hearing this, the model threatened to kill herself if the painter married another woman. The painter threw open the window and told her to go ahead. The woman jumped out of the window, breaking both of her legs, and the painter married her out of remorse.

In relating the framed tale, the narrator discloses his own unreliability. He describes women as equally sincere and false, with a willingness to do anything to get what they want, "and they always succeed, especially when marriage is the object" (Maupassant 250). This suggests that the model was actually manipulating the painter into marriage by jumping out of the window and removes any blame from the painter for 
goading her into the jump. However, as the narrator was the person who first told the woman that the painter had plans to marry someone else, the narrator has an interest in suggesting that the model is entirely to blame. By disparaging the characters of the model and of women in general, the narrator places all of the blame on the model and frees himself from responsibility for the woman's injury.

Mark Twain develops a somewhat different use for the frame narrative. In the 1865 story, "The Notorious Jumping Frog of Calaveras County," the frame assists Twain in constructing a "skillful retelling of a well-known tall tale" (Baym 12). The frame creates the ironic tone which permeates the entire story and calls into question the narrator's intentions, ultimately shifting the focus of the tale back onto the reader.

The frame narrator is unnamed and presents the tale from the first person point of view. The opening frame consists of a few lines which explain how the narrator originally learns the framed tale. The narrator states that, at the request of a friend, he calls on Simon wheeler to ask about a man named Leonidas $W$. Smiley. The narrator suggests that there is no man by this name and that his friend has played a joke on him. The mention of the last name, Smiley, incites simon wheeler to tell the story of Jim Smiley, a story which the narrator claims is tedious yet which he chooses to retell. The irony deepens when the reader discovers in the framed story that the 
tale is not tedious and that the narrator has not been the recipient of a joke as much as he has played a joke on the reader.

The framed tale is Wheeler's rendition of the story of Jim Smiley, a man who bets on everything. The last instance given of his gambling is the story of his frog that could outjump any other frog in Calaveras County. When wheeler finishes this tale, he breaks off his narrative because someone has called him from the yard. The unnamed narrator returns to narrate the closing frame in which he attempts to leave, encounters wheeler returning from the yard, and escapes before Wheeler can continue his tale of Jim Smiley. In the closing frame, the narrator states that on encountering wheeler again, and "lacking both time and attention. . I did not wait - . but took my leave" (19). This reinforces the opening frame's ironic suggestion that the narrator has been bored by the tale yet retelis it to the reader. It also reminds the reader that, although forewarned, he has read the tale to completion and has been entertained.

Anton Chekhov employs the framework story in some of his short fiction as well. "The Peasant Women," published in 1892, six years before James published The Turn of the Screw, exemplifies a further advance in the use of this convention in short fiction. The opening frame introduces the characters and describes the setting for the frame's tale, which is told from the third-person point of view. A businessman and a young boy 
arrive in the courtyard of Philip Ivanov Kamin, also a businessman. Kamin has a wife, a son, and two daughters-in-law living with him.

In the framed narrative, the businessman, Matvey Savvich, tells Kamin the story of how he came to adopt the orphan boy, Kuzka. Matvey tells of his affair with the boy's mother. When her husband dies of arsenic poisoning, Matvey's testimony helps convince the authorities that the death was not a suicide but that the woman murdered her husband. The woman is convicted of murder and sentenced to thirteen years in a labor camp. She dies of a fever on her way to siberia, and Matvey adopts the orphan she has left behind.

This tale is interrupted at various points by the frame narrator to describe changes in the scene during Matvey's story and to provide Kamin's reaction to the story as it progresses. Each interruption develops not only Kamin's character but those of his family members as well. When Matvey's story ends, the frame narrator continues with the story of Kamin's daughters-in-law. Their desire to be free from their husbands is described as is their reaction to the fate of the woman in Matvey's tale. It is her fate which keeps them from murdering their own husbands. The final passage of the closing frame depicts Matvey's harshness toward Kuzka and suggests that the husband's death might have been suicide and that Matvey might have framed the woman to be free of her. Chekhov's use of the frame narrative is more 
sophisticated than that of framework stories published earlier in the century. In this tale, the framework is equally as important as the framed narrative and both tales work to develop each other reciprocally. The framework, particularly the closing frame, enriches the framed tale of the peasant woman. At the same time, the framed narrative enriches the plot of the framework as the characters respond to Matvey's story and adjust their actions accordingly.

Since its earliest use in presenting collections of stories through its development in long and short fiction, the frame narrative has been a standard convention in literature. In 1898, James takes the development of the frame narrative to its most advanced stage in The Turn of the Screw. Through the omission of a closing frame, the reciprocal authority between narrators, and the dialogue pattern of incomplete sentences and unsubstantiated assumptions found in the frame and the governess's narrative, James reverses the frame's traditional role of providing credibility and closure for the framed tale. He uses frame narration to cast suspicion on both the opening frame and the framed narrative of the governess's tale, preventing the determination of narrative authority and denying closure in the novella, thereby constructing a tale of insoluble ambiguity. 
CHAPTER IV

\section{A STRUCTURAL EXAMINATION OF FRAME NARRATION IN THE TURN OF THE SCREW}

James prevents the reader from initially recognizing the text's ambiguity by combining traditional uses with his nontraditional uses of the frame narrative. Peter A. Obuchowski notes that two of James's conventional uses for the frame are to give the appearance of reality to a supernatural tale and to provide background information on the narrator of the framed narrative (Obuchowski 381). The reader, familiar with this technique, assumes that James is using the frame to this end and does not immediately consider that the information in the frame might be suspect. This explains why the first reviews and readings of the novella, in trusting Douglas's validation of the governess's authority, followed the apparitionist interpretation. It also explains why critics continue to overlook many of the non-traditional elements in James's use of the frame narrative, elements such as his omission of a closing frame.

By using only an opening frame, James has denied closure to the novella and to the reader. A closing frame, as obuchowski suggests, would open the door to questions from Douglas's listeners regarding the aftermath at Bly (382). Obuchowski does not acknowledge that this is a direct result 
of omitting a closing frame, but this is the closest that any critic has come to noting this important point. Some of the questions that would arise from Douglas's listeners have been posed by critics, such as the existence of the ghosts, the reality of Miles' death, and the possibility that Douglas is Miles. A closing frame would also require additional narration by the frame narrator which could possibly determine narrative (un)reliability not only for the frame narrator but for the governess as well.

The intentional lack of closure is also suggested by the fact that the tale is presented to the characters of the prologue in sections. The narrator of the frame acknowledges that Douglas reads the governess's manuscript over a series of evenings, stating "The whole thing took indeed more nights than one" (James 298). The tale was also presented to James's first reading audience in sections. The initial publication of the tale came in a series of twelve installments in Collier's Weekly. Opportunities existed for providing closure either at the conclusion of each installment or at the end of the story without risking narrative intrusion. James's refusal to provide closure to any of the installments and, once published as a complete novella, his refusal to present the governess's tale within a series of smaller framed narratives as told to Douglas's listeners, suggests that the text's lack of closure and the resulting ambiguity are intentional.

The text's ambiguity is not only dependent on the 
omission of the closing frame but also on the structure of the opening frame. In realizing that no closing frame has been provided to answer questions regarding the governess's tale, the reader is forced back to the opening frame in search of information. James has relied on the reader's familiarity with frame narration and has used this against the reader, providing unreliable information in the frame knowing that the reader will initially assume that the information is reliable. To a reader searching for clues as to the reliability of the governess's narrative, the information in the frame appears to resolve the ambiguity of text.

The appearance of resolved ambiguity is based in part on the fact that the prologue temporally frames the governess's narrative. Only one critic, Shoshana Felman, has provided an extensive examination of this information. However, the conclusions she draws from this examination are at times inaccurate and overlook the significance of the frame's structure. Felman notes that James has temporally framed the governess's tale by relating events which occurred before Bly through a prologue which occurs after Bly (Felman 120). She suggests that the prologue acts as an epilogue, but she does not consider the prologue in terms of the technique of frame narration wherein the prologue acts as both an opening and a closing frame. While it is important that the prologue occurs after Bly and mentions events that occur before Bly, the chronological point of the prologue's telling is not the 
primary reason for the appearance of resolved ambiguity. It is the fact that the prologue describes events which occur after Bly that creates this appearance. By including information on the governess, her later employment and her character after Bly, the prologue creates the illusion of closure.

A close reading reveals, however, that instead of providing closure, James has only divided the tale's origin, temporally positioning it both before and after the governess's text so that it appears as a beginning and an ending when in fact it is two different origins: the origin of the tale's action and the origin of the tale's telling. As Felman notes

the frame picks up the story, then, both after its end and before its opening. If the function of the frame is to determine the story's origin, then that origin must somehow be both anterior and posterior to the story [italics Felman] (Felman 120).

That the story's origin is both anterior and posterior to the story applies not only to the origin of the governess's narrative but to the frame narrative as well. Each narrative presented in The Turn of the screw contains its own posterior and anterior origin. The information told by the frame narrator constructs a posterior origin for the frame by relating the fireside scene long after the fact. By including information leading up to Douglas's narrative as well as the governess's tale, the frame narrator also constructs an anterior origin for the frame as well. The same elements of the frame that construct its own anterior and posterior 
origins also construct them for Douglas and the governess. The frame narrator provides a posterior origin for Douglas by describing Douglas's telling of the governess's story many years after it actually occurred. The narrator also provides an anterior origin for Douglas by describing Douglas's actions that led up to his story of the governess. Douglas, in turn, provides a posterior origin for the governess by describing her after the events at Bly. He also provides an anterior origin for the governess by describing the events prior to her employment at Bly. The prologue, then, temporally frames not only the governess's narrative but the narratives within the frame.

Felman describes the framing of these narratives as the result of a "narrative chain, in which the narrators relay the story from one to the other [italics Felman]" (121). She notes that the chain involves the passing along of manuscripts as well as of oral storytelling and views the result of the narrative chain as an "echoing effect" that defers the assigning of a narrative voice to take responsibility for the tale (121). According to Felman, the frame repeats itself in an infinite reproduction of the act of narration which results in situating the story's origin "in a forgetting of that origin: to tell the story's origin is to tell the story of that origin's obliteration" (122).

However, the repetition of framing enacted within the prologue is not infinite. It is limited to four instances. 
Douglas provides a frame for the governess's narrative, the frame narrator provides a frame for Douglas's narrative, and subsequently, for the governess's narrative as well. In this context, the frame narrator actually provides a double frame which encloses the narratives of Douglas and the governess. Within Douglas's narrative is the fourth instance of framing, the summary of the governess orally relating the events at Bly to Douglas. By telling him about the events which led up to her experience at Bly, the governess provides her own opening frame. Douglas, in re-telling these events, provides a closing frame.

As the repetition of framing is limited to the above four instances, there is no loss of the story's origin but rather an extension of the story in which the origins of a number of shorter stories or prologues are also contained. James has not obliterated the origin of the tale so much as he has provided a number of tales within tales, each with its own frame, giving the appearance of authority to each subsequent narrator within the series of framed stories. If each layer of framing is pared away, however, one is still left with origins for the stories but not with a basis for narrative reliability in the relating of the stories. In constructing a series of multiple frames, each told within an exterior tale yet based on an interior tale, the stories and their origins exist; however, they exist simply as stories with no reliable narrative voice by which to determine whether any or all of the stories are 
true or false.

To the extent that Felman finds the repetition of frames to be at the root of the question of narrative authority, she is correct. However, she inaccurately suggests that the story's origin seems to depend on the authority of the narrator, "who is usually supposed to be both the story's literal source and the depositary of the knowledge out of which the story springs and which the telling must reveal" (120). True, the narrator is the story's literal source and the depositary of the knowledge out of which it springs, but this is not dependent upon narrative authority. If a narrator relates a story that is untrue or inaccurate, the narrator is still the story's literal source. The story has been told. The narrator also remains the depositary of knowledge, the knowledge of the story that has been related, regardless of whether that knowledge is accurate or inaccurate. James demonstrates that the telling of a story, while it reveals the narrator's knowledge out of which the story springs, does not necessarily reveal a means of establishing authority for the story's teller through the revelation of that knowledge.

Felman also suggests that the inability to determine narrative authority stems from the fact that the prologue does not relate but "disconnects" the story from its narrator because it introduces three narrators instead of one (121). However, she overlooks the paradox in this disconnection. The frame disconnects the story from the narrators precisely 
because the frames, framed stories, and narrators are so intricately connected. The authority of each narrator is built upon the appearance of another narrator's authority. If one narrator's authority becomes suspect, then the facts presented in that narrator's frame become suspect as do the facts presented in the ensuing framed narrative. It also affects the reliability of any other narrators who have vouched for the credibility of the now suspect narrator. For instance, if as Obuchowski suggests, the frame narrator is biased toward Douglas (Obuchowski 382), or as Murphy states, the frame narrator is biased toward the bachelor uncle (Murphy 549), then the frame narrator's reliability is suspect. This affects the narrator's opinion that Douglas is a reliable source for validating the governess's narrative, thereby undermining the narrative authority of the governess as well. If, on the other hand, one considers the frame narrator to be reliable, then Douglas becomes a reliable character and Douglas's opinion that the governess's narrative is accurate is upheld as well.

Critics have debated the number of narrators in the novella. Some, such as Felman and Obuchowski, consider Douglas to be a narrator so that, included with the frame narrator and the governess, there are three narrators introduced in the frame. Others, such as Kevin Murphy, correctly believe that Douglas is a character. Douglas's information is presented through a series of quotations and paraphrases which are contained within the frame narrator's presentation of the 
prologue. His one long quote concerning his relationship with the governess when she worked for his family appears as a narrative and blurs the distinction between narrator and character; however, it is still related through the point of view of the frame narrator. By assigning Douglas a proper name rather than leaving him unnamed, like the frame narrator and the governess, James further indicates the definition of Douglas as a character rather than as a narrator.

Defining Douglas's role as a character is important in revealing that the narrative reliability of the frame narrator and the governess is an illusion. Douglas is the sole reference for their authority. Traditionally, narrative authority can be determined by comparing the internal and external contexts of the narrator. The narrator's relationship to the characters and events within the text, such as omniscience or limited omniscience, and the existence of the narrator as a character within the story or as someone completely outside of the story provides the narrator's internal context.

A narrator's external context is the context in which the narrator tells the story. It includes the narrator's motive for telling the story as well as any biases or limitations that could affect the manner in which the story is told. The external context is the context in which the narrator is charged by the implied author with the responsibility of narrating the text. In The Rhetoric of Fiction, wayne Booth 
defines the implied author as the scribe of the text, the writer created by the author to serve as the author's second self $(70-71)$. Philip J. M. Sturgess, in Narrativity: Theory and Practice, suggests that if a narrator agrees with the norms of the implied author, the authentic norms of the work which are suggested to the reader by concealed authorial prompting, then the narrator is reliable. If the narrator disagrees, then the narrator is unreliable (169).

In The Turn of the screw, however, the information is presented in such a way as to eliminate the possibility of determining the norms of the implied author and therefore the authority of the narrators. In other words, no external context is provided for the narrators. Felman recognizes the result of this lack of external context. However, she attributes it to the existence of three narrators and the echoing of narrative voices which occurs in the frame:

the frame leaves no one out: it pulis the outside of the story into its inside by enclosing in it what is usually outside it: its own readers. But the frame at the same time does the very opposite, pulling the inside outside: for in passing through the echoing chain of the multiple, repetitive narrative voices, it is the very content, the interior of the story which becomes somehow exterior to itself . . . The frame is therefore not an outside contour whose role is to display an inside content: it is a kind of exteriority which permeates the very heart of the story's interiority, an internal cleft separating the story's content from itself, distancing it from its own referential certainty. With respect to the story's content, the frame thus acts both as an inclusion of the 
exterior and as an exclusion of the interior: it is a perturbation of the outside at the very core of the story's inside, and as such, it is a blurring of the very difference between inside and outside [italics Felman](123).

While Felman mentions the "inclusion of the exterior and - . exclusion of the interior" of the text, she does not realize that this applies first and foremost to the narrators, that their external context is only an illusion substantiated through the construction of their internal context. The result is that the narrators are distanced from their own "referential certainty." It is precisely because Douglas is a character that this process of inclusion and exclusion occurs. The reliability of the frame narrator and of the governess is based solely on the opinion of a character, Douglas, who exists completely within the context of the narrated text and whose reliability is based on the authority of the narrators. If Douglas had been a narrator, he would have had an existence both inside and outside of the text, an external existence that could have been used to help define the norms of the implied author and to determine the reliability of the other narrators. As a character, he is unable to do this.

The Turn of the Screw is unique, then, because there is no external context for the narrators. The appearance of an external context exists, however, because of the passage of time between the multiple frames within the novella. Douglas appears to provide an external context for the governess and the frame narrator appears to provide an external context for 
Douglas. This external context, however, is impossible to construct. It depends on the ability of Douglas as a character to move outside of the text and redefine himself as a narrator, a narrator who is either representing or misrepresenting the norms of the implied author, whose own reliability can be determined, and who can be used to determine the reliability of the frame narrator and the governess.

The novella substitutes multiple frames in the place of external contexts for the narrators, frames which give the appearance of establishing narrative authority. Each frame removes the narrator from the narrated text and gives the appearance of an external context, but that external context exists only in relation to the framed text which it precedes. There is no true external context provided by an implied author to bridge the gap between the inside and the outside of the text of the entire novella. Just as the omission of a closing frame forces the reader back to the opening frame for information, the lack of an external context for the narrators forces the reader to rely on their internal context as the sole means of determining narrative authority. In this way, the narrators' authority is completely determined through the opinion of, and information provided by, Douglas, who exists solely within the text. The tautological result is that, while Douglas's reliability rests on the opinion of two narrators, their authority is based on Douglas, a condition of 
reciprocity which makes it impossible to determine the actual reliability of the narrators and of Douglas.

The reciprocal authority shared by the narrators and Douglas divides the novella, in Felman's terms, between two couples: the governess and Douglas; Douglas and the frame narrator (Felman 130). In such a division, Douglas functions as a pivot, receiving his authority from both narrators and imparting authority to each narrator in return. This reciprocation creates the illusion of authority rather than providing a textual basis for it.

The governess appears to be a reliable narrator because Douglas vouches for her character and the reader extends this to include her narrative authority. Felman suggests that Douglas's belief in the governess is the result of his infatuation with her and that it adds faith to the literality of her narrative (Felman 131). Obuchowski also notes that the reader has no reason to suspect the governess's narrative based on Douglas's words (Obuchowski 382). Douglas's words, however, are only a testimony to his opinion of her character. For instance, he states that "She was the most agreeable woman I've ever known in her position" (James 2). That Douglas believes in his own description of the governess and in the validity of her story is further supported by his having possession of the governess's manuscript. The fact that he kept it for more than twenty years suggests that he considers it to be an accurate account of an important story which 
contributes to the appearance that the governess is reliable. Douglas's possession of the manuscript is also one means by which the governess reciprocally validates Douglas's authority. The reader already trusts Douglas's opinion of the governess because he met her in person and had the opportunity to evaluate her character before he heard her story. He also heard her story first-hand. By witnessing her mannerisms, facial expressions, and voice intonations while she told the story, he was theoretically able to form a judgment of her reliability. By producing the governess's manuscript, Douglas's authority is further validated because it suggests that the governess trusted him to be the keeper of her tale. As he states in the frame, if the governess had not liked him, she would not have told him about Bly (2). The reader assumes that because the governess liked Douglas he must be a reliable source, just as Douglas's statement that he liked the governess is used to support her appearance of reliability.

A closer examination of this assumption, however, reveals that Douglas's possession of the manuscript only appears to validate Douglas's facts and opinions. It actually validates the governess's faith in his re-telling of her story, in his ability to accurately recount the facts about her past and about her employment at Bly as she told them to him. It does not provide any basis for Douglas's ability to evaluate the governess's character or her narrative reliability but simply depicts what Felman terms "the rapport" between them. In fact, 
it is precisely this rapport, the governess's faith in Douglas and his faith in the governess, that has led critics to question not just the governess's reliability but Douglas's as well. Douglas's arguable reliability regarding the governess is further compounded by the suggestion from one of the prologue characters, Mrs. Griffin, that Douglas was in love with the governess. Murphy considers Mrs. Griffin's comment to be proof of Douglas's bias toward the governess (Murphy 548). Obuchowski more accurately points out that the reader simply does not know the truth about the relationship between the governess and Douglas, but he also suggests that Douglas could have altered the manuscript out of "love or infatuation" (Obuchowski 382). In addition to the governess, there is only one other means of determining Douglas's authority. The frame narrator also creates the illusion that Douglas is reliable. However, the frame narrator's reliability depends upon Douglas and their condition of reciprocal authority is based on the subtle construction of the impression that the narrator and Douglas are able to interpret each other's thoughts and physical movements, and to complete each other's sentences.

The first step in the construction of the reciprocal authority between the frame narrator and Douglas is for the frame narrator to establish reliability by creating the impression that Douglas, the physical link to the governess's tale, considers the narrator to be reliable. However, in order to use Douglas to establish reliability, the narrator must 
simultaneously suggest Douglas's reliability and do so by creating the impression that Douglas is interested in presenting an accurate recounting of the governess's tale. There are a number of instances in which the narrator suggests that Douglas is concerned with a reliable re-telling of the governess's tale, such as Douglas's refusal to begin the tale without the written manuscript. The frame narrator considers this to be evidence of Douglas's scruples, noting "The others resented postponement, but it was just his scruples that charmed me" (James 3). The word "scruples" places Douglas's telling of the governess's tale in an ethical context which assists in the suggestion that Douglas is reliable. The frame narrator also states that Douglas believed the governess's narrative "required for a proper intelligence a few words of prologue" (4), again suggesting that accuracy in the telling and in the reader's understanding were of the utmost importance to Douglas. However, these instances only create the illusion of reliability. They actually suggest that Douglas intends to recount the information accurately, but they do not provide proof that he succeeds in his intention. The illusion of Douglas's reliability, however, is the first step in constructing authority for the frame narrator even though it is merely based on the narrator's ability to quote Douglas's statements, summarize his information, and interpret the intentions behind his gestures and comments.

Once Douglas appears to be reliable, it must be shown 
that Douglas supports the frame narrator. This is the second step in constructing the frame narrator's authority. The narrator admittedly wrote down the events of the prologue long after the events had transpired, so the accuracy of the transcription is subject to the narrator's memory as much as to his/her (in)ability to interpret Douglas's intentions. Regardless of the accuracy of the transcript, its content contains many instances in which Douglas is used to establish the frame narrator's authority. For example, by giving the frame narrator the governess's manuscript, Douglas depicts his faith in the frame narrator much as the governess affirmed her faith in Douglas when she passed her manuscript on to him. In both instances, this faith appears to, but does not, establish narrative reliability.

The frame narrator also makes assumptions regarding Douglas's physical movements which further the appearance of narrative reliability. The first of these assumptions occurs in the opening paragraph when the frame narrator observes Douglas's reaction to a ghost story:

Some one else told a story . . which I saw he [Douglas] was not following. This I took for a sign that he had himself something to produce and that we should only have to wait. We waited in fact till two nights later; but that same evening, before we scattered, he brought out what was in his mind [italics mine] (1).

In relating the governess's tale to the listeners in the prologue, Douglas confirms the frame narrator's assumption that by not paying attention to a particular ghost story 
Douglas indicated that he had something to share. As this occurs in the first paragraph of the frame, it subtly suggests the narrator's ability to interpret Douglas throughout the remainder of the frame.

This first instance of accurate assumption is followed almost immediately by another example. Douglas admits that he has never heard a story which comes near to touching the governess's tale and the frame narrator asks, "For sheer terror?" (1). The narrator then interprets Douglas's response, assuming that "he seemed to say it wasn't so simple as that [italics mine]" (1). Douglas then "passed his hand over his eyes, made a little wincing grimace. 'For dreadful dreadfulness!" $(1-2)$. As with the first instance, the narrator's language alludes to the shift from reporting a fact such as "He passed his hand over his eyes" to making an assumption about Douglas's intentions such as "This I took for a sign" or "He seemed to say . . ." Later in the prologue, these indications vanish, blurring the distinction between reports of action and assumptions of intention.

The above example is important for an additional reason beyond the narrator's attempt to interpret Douglas's physical movements. Douglas corrects the narrator's assumption. The correction, however, is slight due to the similarity between "terror" and "dreadfulness," and it appears as further clarification rather than a complete correction to an inaccurate assumption. Only one instance occurs in the frame 
of Douglas firmly correcting an assumption made by the narrator. When Mrs. Griffin asks who the governess was in love with, the narrator states, "The story will tell," and Douglas responds "The story won't tell . . not in any literal vulgar way [italics James]" (3). This single instance of Douglas explicitly correcting the frame narrator contributes to the suggestion that the other assumptions made by the narrator are correct. If Douglas corrected one error, the reader assumes he would correct any other errors. Douglas's silence after a statement by the narrator appears as Douglas's agreement with the statement even though there is no conclusive proof of this agreement.

In addition to the suggestion that the narrator is able to interpret Douglas's intentions and physical movements and that Douglas would have corrected any erroneous statements made by the narrator, Douglas and the narrator follow a specific dialogue pattern throughout the frame. This dialogue pattern is the final step in constructing their condition of reciprocal authority. It is comprised of incomplete sentences and unsubstantiated assumptions, with the narrator elaborating on Douglas's comments and Douglas completing the narrator's sentences. The result is the appearance that the narrator and Douglas have a special understanding beyond that of the other characters in the prologue.

The narrator admits to feeling as if he/she has been singled out by Douglas as the person most likely to understand 
the governess's story and creates the impression that, as someone selected by Douglas, he/she is a reliable narrator. For instance, when Douglas suggests that he send for the governess's manuscript, the narrator states, "It was to me in particular that he appeared to propound this - appeared almost to appeal for aid not to hesitate" (2). A few paragraphs later, Douglas states that the governess never told anyone but himself of the events at Bly and a listener questions whether that was because the events were so frightening. The frame narrator describes Douglas's response, "He continued to fix me. 'You'll easily judge,' he repeated: you will [italics James]" (3). The reader does not initially recognize that no evidence exists to support the narrator's feeling of selfimportance other than the narrator's own opinion. However, the narrator has already convinced the reader in the opening paragraphs that he/she is capable of interpreting Douglas's intentions, so the reader trusts the narrator's belief in his/her own importance.

The narrator's position of importance appears to be substantiated by the narrator's ability to elaborate on Douglas's comments whenever he pauses. Kevin Murphy notes "In his slow revelation of the tale's background, Douglas engages in a series of pregnant pauses that are calculated to involve, or at least have the consequence of inciting, the participation of his audience" (540). The audience's participation functions in two ways, both of which suggest a 
lack of understanding by all of the listeners except for the narrator. When audience members make inconsequential comments, such as one woman's cry of "'Oh how delicious!" "after Douglas admits that the story is dreadful (2) or Mrs. Griffin's admission that she only understands stories told in a literal and vulgar way (3), they act as a contrast to the narrator.

In other instances, the narrator feels that he/she alone has understood Douglas's comment but must elaborate on it for the benefit of the other Iisteners. When Douglas states that the governess has accepted the position at Bly, the narrator adds

And Douglas, with this, made a pause that, for the benefit of the company, moved me to throw in - 'The moral of which was of course the seduction exercised by the splendid young man [bachelor uncle]. She succumbed to it' (6).

The narrator has interpreted this information from Douglas's comments even though Douglas never directly confirms that the reason for the governess's acceptance of the position was her seduction by the bachelor uncle. This suggests that the narrator alone is able to interinet Douglas's comments and must elaborate on them to ensure the understanding of the other listeners.

In addition to the narrator's ability to elaborate on Douglas's comments, Douglas demonstrates the ability to complete the narrator's sentences. When a listener questions Douglas as to the cause of the former governess's death, the 
narrator states, "In her successor's place.. . I should have wished to learn if the office brought with it -" and Douglas interjects "Necessary danger to life?" (5). It appears that once again the narrator and Douglas are communicating with each other, each participating in the re-telling of the governess's tale, beyond the abilities of the other listeners. Murphy notes that Douglas had many different ways of completing the narrator's sentence but that he chose the one which "sums up the drift of his forth-coming tale" (540). He also suggests that

if we look at what precedes the remark,
there is no reason to suppose that
Douglas's completion would have been
exactly or even roughly the same as the
narrator's. The narrator is more than
happy to accept Douglas's completion
since it marks him as an acute, as
opposed to a literal-minded or vulgar,
listener, and thus he continues, with
increasing confidence, to collaborate in
the anticipations $(540-41)$.

Murphy correctly notes that the narrator is ready to accept Douglas's completion because it substantiates his/her role as an acute listener. After the subtle development of the narrator's ability to interpret Douglas's intentions and elaborate on his comments, Douglas's completion of the narrator's sentence becomes the final step in establishing reciprocal authority between the narrator and Douglas. Murphy inaccurately supposes, however, that this provides evidence of an actual understanding between the narrator and Douglas, that they are "entangled" and that "as the drift of the story 
becomes clearer for Douglas and the narrator, it becomes more elusive for us" (541). The prologue only constructs the appearance of a clear understanding between Douglas and the narrator, which is why the story remains insolubly ambiguous for the reader. No amount of scrutiny can provide reliable facts by which to determine whether or not this understanding exists. It is impossible to prove or to disprove the reliability of the communication between the narrator and Douglas and therefore to determine narrative reliability.

The dialogue pattern that creates the illusion of reliable information disclosed by the frame narrator and Douglas is also followed by the governess. Examples of incomplete sentences and unsubstantiated assumptions are found in her conversations with Mrs. Grose and with Miles. Murphy notes this parallel pattern of communication, stating "As in the prologue, the governess and Mrs. Grose communicate in this fragmented fashion" (544). However, the first example of this type of dialogue involving the governess occurs in the frame between the governess and Douglas. When Douglas describes his walks with the governess during which she told him about the events at Bly, he states "She had never told anyone. It wasn't simply that she said so, but that I knew she hadn't. I was sure; I could see" (James 2). He later acknowledges that the governess had been in love and again demonstrates his belief that they communicated certain information without speaking, stating " . . she couldn't tell her story without its coming 
out. I saw it, and she saw I saw it; but neither of us spoke of it" (3). By this point in the frame, the appearance of Douglas's reliability has already been somewhat established, and the reader has been exposed to the appearance of accurate communication without complete speech through the example of the frame narrator and Douglas. The suggestion that Douglas and the governess can also communicate without speaking therefore appears more plausible than it would if it had appeared earlier in the frame.

The examples of unspoken communication and communication through fragmented sentences that are presented in the frame subtly prepare the reader to accept parallel instances in the governess's narrative. The first dialogue in the governess's narrative depicts the governess and Mrs. Grose communicating without directly stating the subject of their discussion. The governess acknowledges the necessity for this type of communication because "There were naturally things that in Flora's presence could pass between us only as prodigious and gratified looks, obscure and roundabout allusions" (8).

This type of dialogue, however, continues throughout the governess's tale and becomes more important as the validity of the ghosts comes into question. It is used to give the appearance that Mrs. Grose confirms the existence of the ghosts even though there is no evidence that Mrs. Grose supports or rejects the governess's statements. For instance, when the governess describes the man she sees on the tower and 
in the dining room window, it appears that Mrs. Grose identifies the man as Peter quint, the bachelor uncle's deceased valet. As in the frame narrative, however, the governess and Mrs. Grose simply build upon each other's statements, neither confirming nor rejecting what the other has said.

For instance, phrases are repeated and questions are followed by other questions instead of answers. The governess describes the man as an actor and then as a gentleman. Mrs. Grose again repeats the description but in the form of a question, "A gentleman . . a gentleman he?" (24). Instead of answering Mrs. Grose, the governess poses another question, asking, "You know him then?" and Mrs. Grose follows this with still another question, "But he is handsome?[italics James]" By the time Mrs. Grose states Quint's name, it appears that she has reached this identification logically through her conversation with the governess. However, there are no spoken statements to confirm this. It is more likely that each character is inciting the response of the other by remaining elusive. In this way, the responses can be seen as guesses as much as knowledgeable statements, casting suspicion on the information contained in each response.

The possibility that Mrs. Grose is guessing at each stage in the identification of Quint is suggested earlier in the same conversation. The governess states that she has no idea who the man was or where he had gone. Mrs. Grose asks if he 
was a stranger. The governess confirms this and then states that she would now be able to discuss the stranger's appearance since Mrs. Grose had guessed his identity. Mrs. Grose responds "Ah I haven't guessed... How can I if you don't imagine [italics James]" (22). The governess's comment refers to Mrs. Grose guessing that the man was a stranger. Mrs. Grose's comment refers to the fact that, if the governess does not know the man's identity, she could not guess it either. The result of this dialogue is two-fold. It implies that the governess is assuming a certain amount of guess-work in her communication with Mrs. Grose. However, it also suggests that Mrs. Grose will not allow herself to be led into guessing by the governess. Due to the fragmented sentences and lack of direct clarification of meaning by either speaker, there is no way to prove in this instance or later in the conversation that Mrs. Grose is guessing or is knowledgeably identifying the stranger as Peter Quint, leaving the entire identification scene ambiguous.

The governess engages in a similar dialogue with Miles in which each speaker builds upon the assumptions of the other without directly confirming or rejecting any of the information, a dialogue pattern that concludes the last passage of the novella with the apparent identification of Peter Quint by Miles. Miles's comments in the final scene appear more as questions, fragments added on to the governess's statements. The governess screams at her vision of 
Quint "'No more, no more, no more!'" and Miles responds "'Is she here? [italics James]." The governess assumes that by "she" Miles meant Miss Jessel. She responds, "Miss Jessel, Miss Jessel . - It's not Miss Jessel! But it's at the window - straight before us. It's there - the coward horror, there for the last time! [italics James]" (88). The fact that James italicized the words "here" and "there" suggests that Miles might not have known what he was looking for and that the governess had to direct his attention. However, as the governess did not use Quint's name, Miles's statement of "Peter Quint" suggests that he knew of the ghost's presence but did not want to admit it. The result is that even the final identification scene is ambiguous. As the entire novella has conveyed spoken information through this pattern, Miles could either be knowledgeably identifying Quint or guessing in an attempt to answer the governess's challenge to name "the coward horror." In fact, his final words are a combination of these two possibilities "'Petur Quint - you devil!' His face gave again, round the room, its convulsed supplication. 'Where? [italics James]'" (88).

The above examples of dialogue in the governess's narrative depict the consistent use of a pattern of incomplete sentences and unsubstantiated assumptions. This pattern creates the impression that other characters support the reality of the ghosts, thereby establishing the illusion of narrative authority for the governess. The reader accepts the 
illusion because the frame narrative has already used the same pattern of dialogue to establish the appearance of authority for the frame narrator and for Douglas. On closer examination, however, the dialogue within the frame and within the governess's narrative cannot be used to prove the reliability or unreliability of a narrator but leaves the question of narrative authority insolubly ambiguous.

The dialogue pattern in the frame and in the governess's narrative parallels the construction of reciprocal authority and the use of a single frame. Each of these elements is used to prevent narrative reliability and closure in the novella. This is a significant departure from traditional framework stories in which a narrator's reliability can be determined either in the frame or the framed story, and which concludes with a closing frame. In the Turn of the screw, narrative reliability and closure are only illusions which leave the reader with a novella of insoluble ambiguity. 


\section{CHAPTER V}

\section{CONCLUSION}

The Turn of the Screw has been the subject of diverse critical interpretation since its first appearance in 1898. Beginning with the apparitionist reading at the turn of the century and continuing through Freudian, psychoanalytic, mythological, structuralist, reader-response, linguistic, and new-historical interpretations, the novella has consistently reflected the changes in critical theory throughout the twentieth century.

While each interpretation focused primarily on a single issue, such as the validity of the ghosts, the presence of archetypes in the text, or the possible source for James's tale, the separate approaches did not so much rule each other out as they built upon each other. Each new reading of The Turn of the Screw was an attempt to examine aspects of the text that previous readings had overlooked or undervalued. For instance, Robert Heilman's extensive examination of the text as a Christian allegory was at least in part incited by the allegations of Freudian critics that the governess was sexually repressed and that the ghosts were hallucinations.

The process of responding to, and building on, previous criticism eventually led the way to the recognition that no 
one reading could resolve the ambiguity in James's text. Reader-response critics, in accepting that the work was insolubly ambiguous, shifted the critical focus from attempting to answer the ambiguity of the text to determining how the structure affected the reader and how it contributed to the novella's complex critical history. It was this focus on structure that finally resulted in critical examinations of the opening frame. However, these examinations were limited. In some instances, the primary focus was still the governess's narrative with only a few references to the opening frame. In others, the frame was explored more thoroughly but with the wrong intent. Reader-response critics, by focusing on the text's effect and then searching for the cause of that effect, began with the critical history and sought to explain it through an examination of the frame. Had critics examined the frame and then determined its relevance to the critical history, the importance of the frame narrative might have been discovered in the 1970s. However, it was the failure of this theory to recognize the extent of the frame's importance that offered important suggestions for future examinations of the text.

The critical history of the Turn of the screw, and in particular the work of reader-response critics, demonstrates the importance of thoroughly examining the literary text before attempting critical interpretation. Even though each critical insight responds to the work of previous critics, the 
literary text must remain the foundation upon which new insights are based. The text in its entirety must be examined to determine how the work adheres to and departs from literary tradition. It is only when this determination is made, and is considered with respect to previous critical analyses of the text, that future insights will be achieved. 
Works Consulted and Cited

Abrams, M.H. et. al. eds. The Norton Anthology of English Literature. 3rd ed. New York: Norton, 1975.

Allott, Miriam. "Mrs. Gaskell's "The Old Nurse's Story': A Link Between 'Wuthering Heights' and 'The Turn of the Screw.'" The Turn of the Screw. By Henry James. Ed. Robert Kimbrough. New York: Norton, 1966. 142-144.

Amoros, Jose Antonio Alvarez. "Possible-Worlds Semantics, Frame Text, Insert Text, and Unreliable Narration: The Case of The Turn of the Screw," Style 25.1 (1991): $42-70$.

The Arabian Nights Entertainments. Trans. Henry Torrens, Edward Lane, John Payne. New York: Heritage P, 1955.

Armstrong, Paul B. "History and Epistemology: The Example of The Turn of the Screw," New Literary History: A Journal of Theory and Interpretation 19.3 (1988): 693-712.

Barry, John D. "On Books at Christmas." The Turn of the Screw. By Henry James. Ed. Robert Kimbrough. New York: Norton, 1966. 173.

Baym, Nina, et. al. eds. The Norton Anthology of American Literature. 2nd ed. 2 vols. New York: Norton, 1985.

Beidler, Peter G. Ghosts, Demons, and Henry James: The Turn of the Screw at the Turn of the Century. Columbia: $\mathrm{U}$ of Missouri P, 1989.

Bell, Millicent. "Class, Sex, and the Victorian Governess: James's The Turn of the Screw." New Essays on Daisy Miller and The Turn of the Screw. Ed. Vivian R. Pollack. Cambridge: Cambridge UP, 1993. 91-119.

- - Meaning in Henry James. Cambridge: Harvard UP, 1991.

Bender, Claire E. A Concordance to Henry James's The Turn of the Screw. New York: Garland, 1988.

Boccaccio, Giovanni. Decameron. Trans. Richard Aldington. Garden City: Garden City, 1930. 
Booth, wayne c. The Rhetoric of Fiction, 2nd ed. Chicago: $\mathrm{U}$ of Chicago P, 1983.

Bronte, Emily. Wuthering Heights. New York: Signet Classics The New American Library, 1959.

Cargill, Oscar. "Henry James as Freudian Pioneer." $A$ Casebook on Henry James's The Turn of the Screw. Ed. Gerald Willen. New York: Thomas Y. Crowell, 1960. 223-238.

- - - "The Turn of the Screw and Alice James." The Turn of the Screw. By Henry James. Ed. Robert Kimbrough. New York: Norton, 1966. 145-168.

Caws, Mary Ann. Reading Frames in Modern Fiction. Princeton: Princeton UP, 1985.

Chamberlain, Daniel Frank. Narrative Perspective in Fiction: A Phenomenological Mediation of Reader, Text, and World. Toronto: U of Toronto P, 1990.

Chase, Dennis. "The Ambiguity of Innocence: The Turn of the Screw," Extrapolation 27.3 (1986): 197-202.

Chekhov, Anton. Forty Stories. Trans. Robert Payne. New York: Vintage Classics-Random House, 1991.

Chinitz, Iisa G. "Fairy Tale Turned Ghost Story: James's The Turn of the Screw," The Henry James Review 15.3 (1995): $264-285$.

Corse, Sandra. "From Narrative to Music: Benjamin Britten's The Turn of the Screw," University of Toronto Quarterly $51.2(1981-82)$ : 161-174.

Costello, Donald P. "The Structure of The Turn of the Screw," Modern Language Notes Apr. (1960): 312-321.

Davidoff, Judith M. Beginning Well: Framing Fictions in Late Middle English Poetry. London: Associated UP, 1988.

De La Mare, Walter. "Evidence of a Subliminal World." The Turn of the Screw. By Henry James. Ed. Robert Kimbrough. New York: Norton, 1966. 177.

Dry, Helen Aristar and Susan Kucinkas. "Ghostly Ambiguity: Presuppositional Constructions in The Turn of the Screw," Style 25.1 (1991): 71-88.

Edel, Leon. Henry James. Minneapolis: U of Minnesota P, 1960 . 
- - Introduction. The Ghostly Stories of Henry James. By Henry James. New Brunswick: Rutgers UP, 1948. i-xxxii.

- - Introduction. Henry James Stories of the Supernatural. By Henry James. New York: Taplinger, 1970 .

- - . "The Point of View." The Turn of the Screw. By Henry James. Ed. Robert Kimbrough. New York: Norton, 1966. 228-234.

Edel, Leon and Lyall H. Powers. The Complete Notebooks of Henry James. New York: Oxford UP, 1987.

Edel, Leon and Adeline R. Tintner. "The Private Life of Peter Quin(t): Origins of 'The Turn of the Screw," "The Henry James Review 7.1 (1985): 2-4.

Elton, Oliver. "Facts, or Delusions." The Turn of the Screw. By Henry James. Ed. Robert Kimbrough. New York: Norton, 1966.176.

Enck, John J. "The Turn of the Screw and the Turn of the Century." The Turn of the Screw. By Henry James. Ed. Robert Kimbrough. New York: Norton, 1966. 259-268.

Evans, Oliver. "James's Air of Evil: The Turn of the Screw." A Casebook on Henry James's The Turn of the Screw. Ed. Gerald Willen. New York: Thomas Y. Crowell, 1960. 200-211.

Fagin, Nathan Bryllion, "Another Reading of The Turn of the Screw." A Casebook on Henry James's The Turn of the Screw. Ed. Gerald Willen. New York: Thomas Y. Crowell, 1960. 154-159.

Felman, Shoshana. Testimony. New York: Routledge, Chapman and Hall, 1992.

- - "Turning the Screw of Interpretation," Yale French Studies 55/56 (1977): 94-207.

Firebaugh, Joseph J. "Inadequacy in Eden: Knowledge and The Turn of the Screw." A Casebook on Henry James's The Turn of the Screw. Ed. Gerald Willen. New York: Thomas Y. Crowell, 1960. 291-297.

Fleming, Bruce E. "Floundering about in silence: What the Governess Couldn't Say," Studies in Short Fiction 26.2 (1989): 135-143. 
Flick, Arend John. The Problem of Narrative Reliability in Modern Fiction: James, Conrad, Ford. Diss. UC Berkeley, 1983. Ann Arbor: UMI, 1994. 8328874.

Feuerlicht, Ignace. "Erlkonig' and The Turn of the Screw." The Turn of the Screw. By Henry James. Ed. Robert Kimbrough. New York: Norton, 1966. 235-236.

Ginsberg, Robert. "James's Criticism of James." The Turn of the Screw. By Henry James. Ed. Robert Kimbrough. New York: Norton, 1966. 269-273.

Goddard, Harold C. "A Pre-Freudian Reading of The Turn of the Screw." A Casebook on Henry James's The Turn of the Screw. Ed. Gerald Willen. New York: Thomas Y. Crowell, 1960. 244-272.

Goetz, william. "The 'Frame' of The Turn of the Screw: Framing the Reader In," Studies in short Fiction 18.1 (1981): $71-74$.

- - Henry James and the Darkest Abyss of Romance. Baton Rouge: Louisiana state UP, 1986.

Hallab, Mary Y. "The Governess and the Demon Lover: The Return of a Fairy Tale," The Henry James Review.8.2 (1987): 104-115.

Halttunen, Karen. "Through the Cracked and Fragmented Self': William James and The Turn of the Screw," American Quarterly 40.4 (1988): 472-490.

Heilman, Robert. "The Turn of the Screw as Poem." A Casebook on Henry James's The Turn of the Screw. Ed. Gerald Willen. New York: Thomas Y. Crowell, 1960. 174-188.

Hill, Robert W., Jr. "A Counterclockwise Turn in James's 'The Turn of the Screw," "Twentieth Century Literature: A Scholarly and Critical Journal 27.1 (1981): 53-71.

Hoffmann, Charles G. "Innocence and Evil In James's The Turn of the Screw." A Casebook on Henry James's The Turn of the Screw. Ed. Gerald Willen. New York: Thomas Y. Crowell, 1960. 212-222.

Holman, C. Hugh and William Harmon, eds. A Handbook to Literature. 5th ed. New York: Macmillan, 1986.

Howard, Patricia. "Myfanwy Piper's The Turn of the Screw." Benjamin Britten, The Turn of the Screw. Ed. Patricia Howard. Cambridge: Cambridge UP, 1985. 23-62. 
James, Henry. The Turn of the Screw and other short Novels. New York: New American Library, 1980.

- - - The Turn of the Screw. Kimbrough, Robert, ed. New York: Norton, 1966 .

Jones, Alexander E. "Point of View in The Turn of the Screw." A Casebook on Henry James's The Turn of the Screw. Ed. Gerald Willen. New York: Thomas Y. Crowell, 1960. 298-318.

Jones, Vivien. "Henry James's The Turn of the Screw." Benjamin Britten, The Turn of the Screw. Ed. Patricia Howard. Cambridge: Cambridge UP, 1985. 1-22.

Jolly, Roslyn. Henry James: History, Narrative, Fiction. Oxford: Clarendon P, 1993.

Kaufman, Linda S. "The Author of Our Woe: Virtue Recorded in The Turn of the Screw," Nineteenth-Century Literature $36.2(1981)$ : $176-192$.

Kenton, Edna. "Henry James to the Ruminant Reader: The Turn of the Screw." A Casebook on Henry James's The Turn of the Screw. Ed. Gerald Willen. New York: Thomas Y. Crowel1, 1960. 102-114.

Kolve, V.A. and Glending Olson, eds. The Canterbury Tales: Nine Tales and the General Prologue. By Geoffrey Chaucer. New York: Norton, 1989.

Lewis, R. W. B. Introduction. The Turn of the screw and Other short Fiction by Henry James. New York: BantamDoubleday, 1988. vii-xix.

Lind, Sidney E. "The Turn of the Screw: The Torment of the Critics," The Centennial Review 14.2 (1970): 225-240.

Lydenberg, John. "The Governess Turns the Screws." A Casebook on Henry James's The Turn of the Screw. Ed. Gerald Willen. New York: Thomas Y. Crowell, 1960. 273-290.

"Magic of Evil and Love. An Extraordinary New Volume from Henry James." The Turn of the Screw. By Henry James. Ed. Robert Kimbrough. New York: Norton, 1966. 169.

Mansell, Darrel. "The Ghost of Language in The Turn of the Screw," Modern Language Quarterly 46.1 (1985): 48-63.

Matheson, Terence J. "Did the Governess Smother Miles?" Studies in Short Fiction 19.2 (1982): 172-175. 
Matthiessen, F. O. and Kenneth B. Murdock, eds. The Notebooks of Henry James. New York: George Braziller, 1955.

Maupassant, Guy de. The Complete Works of Guy de Maupassant. Eds. Alfred de Sumichrast et. al. 17 vols. New York: Pearson, 1910 .

McMaster, Juliet. "The Full Image of a Repetition' in 'The Turn of the Screw." Henry James's "Daisy Miller," The Turn of the Screw, and other Tales. Ed. Harold Bloom. New York: Chelsea House, 1987. 125-130.

McWhirter, David. "In the 'Other House' of Fiction: Writing, Authority, and Femininity in The Turn of the Screw." New Essays on Daisy Miller and The Turn of the Screw. Ed. Vivian R. Pollack. Cambridge: Cambridge UP, 1993. $121-148$.

Milne, Fred L. "Atmosphere as Triggering Device in The Turn of the Screw," Studies in Short Fiction 18.3 (1981): 293-299.

"Most Hopelessly Evil Story." The Turn of the Screw. By Henry James. Ed. Robert Kimbrough. New York: Norton, 1966. 175 .

"Mr. James's New Book." The Turn of the screw. By Henry James. Ed. Robert Kimbrough. New York: Norton, 1966. 175 .

Murphy, Kevin. "The Unfixable Text: Bewilderment of Vision in The Turn of the Screw." Texas Studies in Literature and Language 20.4 (1978): 538-551.

Newman, Beth. "Getting Fixed: Feminine Identity and Scopic Crisis in The Turn of the Screw," Novel 26.1 (1992): 43-63.

Obuchowski, Peter A. "Technique and Meaning in James's The Turn of the Screw." CLA Journal 21.3 (1978): 380-389.

Palmer, James W. "Cinematice Ambiguity: James's The Turn of the Screw and Clayton's The Innocents." Literature/Film Quarterly 5 (1977): 198-215.

Parkinson, Edward J. 'The Turn of the Screw': A History of Critical Interpretations, 1898-1979. Diss. Saint Louis U, 1991. Ann Arbor: UMI, 1994. 9131018.

Pattee, F. I. "The Record of a Clinic." The Turn of the Screw. By Henry James. Ed. Robert Kimbrough. New York: Norton, 1966. 180 . 
Pecora, Vincent P. Modernism and the problem of the Self: Conrad, Joyce, and James. Diss. Columbia U, 1983. Ann Arbor: UMI, 1994. 8327275.

- - -. Self and Form in Modern Narrative. Baltimore: Johns Hopkins UP, 1989.

Phelps, William Lyon. "The 'Iron Scot' Stenographer." The Turn of the Screw. By Henry James. Ed. Robert Kimbrough. New York: Norton, 1966. 178 .

"Psychic Phenomena." The Turn of the Screw. By Henry James. Ed. Robert Kimbrough. New York: Norton, 1966. 175.

Recchia, Edward. "An Eye for An I: Adapting Henry James's The Turn of the Screw to the Screen," Literature/Film Quarterly 15.1 (1987): 1987.

"The Recent Work of Henry James." The Turn of the Screw. By Henry James. Ed. Robert Kimbrough. New York: Norton, 1966. 173.

Reed, Glenn A. "Another Turn on James's 'The Turn of the Screw." A Casebook on Henry James's The Turn of the Screw. Ed. Gerald Willen. New York: Thomas Y. Crowell, 1960. 189-199.

Renner, stanley. "'Why Can't They Tell You Why?' A Clarifying Echo of The Turn of the Screw," Studies in American Fiction 14.2 (1986): 205-231.

Rhead, Clifton. "Henry James and the Sense of the Past." Emotions and Behavior Monographs. Ed. George H. Pollock. New York: International UP, 1987. 263-278.

Roellinger, Francis $X$. "Psychic Research and 'The Turn of the Screw." The Turn of the Screw. By Henry James. Ed. Robert Kimbrough. New York: Norton, 1966. 132-141.

Rohrberger, Mary, ed. Story to Anti-Story. Boston: Houghton, 1979.

Rosenbaum, S. P. "A Note on John La Farge's Illustration for Henry James's The Turn of the Screw." The Turn of the Screw. By Henry James. Ed. Robert Kimbrough. New York: Norton, 1966. 254-258.

Rowe, John Carlos. "Henry James and Critical Theory." A Companion to Henry James Studies. Ed. Daniel Mark Fogel. Westport, CT: Greenwood, 1993. 79-93. 
- - - The Theoretical Dimensions of Henry James. Madison: U of Wisconsin P, 1984.

Royle, Nicholas. "Telepathy: From Jane Austen and Henry James," The Oxford Literary Review 10.1-2 (1988): 43-60.

Rust, Richard Dilworth. "Liminality in The Turn of the Screw," Studies in Short Fiction 25.4 (1988): 441-446.

Scherero, Elliot. "Exposure in The Turn of the Screw," Modern Philology 78.3 (1981): 261-74.

Shelley, Mary. Frankenstein. Toronto: Bantam-Doubleday, 1981.

Siegel, Eli. James and the Children; a Consideration of Henry James's The Turn of the Screw. New York: Definition P, 1968 .

Silver, John. "A Note on the Freudian Reading of 'The Turn of the Screw.'" A Casebook on Henry James's The Turn of the Screw. Ed. Gerald Willen. New York: Thomas Y. Crowell, 1960. 239-243.

Slaughter, Carolyn Overton. Language as Disclosure in Five Modernist American Works. Diss. U of Arizona, 1987. Ann Arbor: UMI, 1987. 8805530.

Slaughter, Martina. "Edmund wilson and The Turn of the Screw." The Turn of the Screw. By Henry James. Ed. Robert Kimbrough. New York: Norton, 1966. 211-213.

Solomon, Eric. "The Return of the Screw." The Turn of the Screw. By Henry James. Ed. Robert Kimbrough. New York: Norton, 1966. 237-244.

Spilka, Mark. "Turning the Freudian Screw: How Not to Do It." The Turn of the Screw. By Henry James. Ed. Robert Kimbrough. New York: Norton, 1966. 245-253.

Stevens, Bonnie Klomp and Larry L. Steward. A Guide to Literary Criticism and Research. Fort Worth: Harcourt, 1992 .

"The Story is . . Distinctly Repulsive." The Turn of the Screw. By Henry James. Ed. Robert Kimbrough. New York: Norton, 1966. 171.

Sturgess, Philip J. M. Narrativity: Theory and Practice. Oxford: Clarendon $P, 1992$. 
Tatlock, John S.P. and Percy MacKaye, eds. The Complete Poetical Works of Geoffrey Chaucer. New York: Macmillan, 1946.

Taylor, Michael J. H. "A Note on the First Narrator of 'The Turn of the Screw," American Literature: A Journal of Literary History, Criticism, and Bibliography 53.4 (1982): 717-722.

Thorp, willard. Introduction. The Turn of the Screw and other Short Novels. New York: New American Library, 1980. vii-xv.

Van Doren, Mark, ed. "James: 'The Turn of the Screw,' A Radio Symposium: Katherine Anne Porter, Allen Tate, Mark Van Doren." A Casebook on Henry James's The Turn of the Screw. Ed. Gerald Willen. New York: Thomas Y. Crowell, 1960. 160-170.

Waldock, A. J. A. "Mr. Edmund Wilson and The Turn of the Screw." A Casebook on Henry James's The Turn of the Screw. Ed. Gerald Willen. New York: Thomas Y. Crowell, 1960. 171-173.

Weber, Jean Jacques. "Frame Construction and Frame Accomodation in a Gricean Analysis of Narrative," Journal of Literary Semantics 11.2 (1982): 90-95.

West, Muriel. "The Death of Miles in The Turn of the Screw." PMLA 76.3 (1964): 283-288.

Whelan, Robert Emmet. "Ordinary Human Virtue: The Key to The Turn of the Screw," Renascence 40.4 (1988): 247-267).

Wilkinson, Myler. "Henry James and the Ethical Moment," The Henry James Review 11.3 (1990): 153-175.

Wilson, Edmund. "The Ambiguity of Henry James." A Casebook on Henry James's The Turn of the Screw. Ed. Gerald Willen. New York: Thomas Y. Crowell, 1960. 115-153.

Wolf, Robert Lee. "The Genesis of "The Turn of the Scew.'" The Turn of the Screw. By Henry James. Ed. Robert Kimbrough. New York: Norton, 1966. 125-131.

Woolf, Virginia. "Henry James's Ghosts." The Turn of the Screw. By Henry James. Ed. Robert Kimbrough. New York: Norton, 1966. 179-180. 
Zacharias, Greg W. Rev. of Ghosts, Demons, and Henry James: The Turn of the Screw at the Turn of the Century, by Peter G. Beidler. The Henry James Review 12.3 (1991): $290-292$. 